\title{
Comparação de dois métodos diagnósticos de escaldadura-das-folhas (Xanthomonas albilineans) da cana-de-açúcar
}

\author{
Alfredo Seiiti Urashima \& Aline Cristine Zavaglia
}

Departamento de Biotecnologia e Produção Vegetal e Animal, Centro de Ciências Agrárias, Universidade Federal de São Carlos, Via Anhanguera Km 174, CEP 13600-000 Araras, S.P.,

Autor para correspondência: Alfredo Seiiti Urashima (alfredo@cca.ufscar.br)

Data de chegada: 10/11/2011. Aceito para publicação em: 02/01/2012.

\section{RESUMO}

Urashima, A.S., Zavaglia, A.C. Comparação de dois métodos diagnósticos de escaldadura-das-folhas (Xanthomonas albilineans) da cana-deaçúcar. Summa Phytopathologica, v.38, n.2, p.155-158, 2012.

A escaldadura-das-folhas (Xanthomonas albilineans) é uma das principais doenças da cana-de-açúcar devido ao dano que causa e à dificuldade da sua correta identificação, especialmente quando a planta, embora infectada, não apresenta sintomas visíveis (fase latente da doença). Essa característica faz com que sua disseminação para novas áreas ocorra através do plantio de toletes aparentemente sadios. A redução na produtividade ocorre quando, em condições de stress hídrico, plantas passam a exibir sintomas crônicos e agudos da doença. Como a maioria das variedades comerciais atualmente cultivadas no Brasil são portadoras assintomáticas da doença, a correta diagnose da doença se constitui numa das principais medidas para o sucesso do controle. O presente trabalho objetivou examinar a eficiências de diferentes métodos diagnósticos de $X$. albilineans. Dados obtidos demonstraram que o método clássico de isolamento do patógeno em meio de cultura a partir da seiva dos internódios do colmo não foi confiável enquanto o método de amplificação por PCR detectou a bactéria em plantas com os três diferentes sintomas da doença.

Palavras-chave adicionais: Diagnose, sintoma latente, DNA, PCR, Saccharum.

\section{ABSTRACT}

Urashima, A.S., Zavaglia, A.C. Comparison of two diagnostic methods for leaf scald (Xanthomonas albilineans) of sugarcane. Summa Phytopathologica, v.38, n.2, p.155-158, 2012.

Leaf scald (Xanthomonas albilineans) is one of the major diseases of sugarcane due to the damage it causes and to its difficult identification, especially when the plant, although infected, does not exhibit visible symptoms (latent phase of the disease). This feature allows the occurrence of its dissemination to new areas through the planting of apparently healthy bud setts. Yield losses occur when plants, under water stress condition, exhibit chronic or acute symptoms of the disease. As the majority of commercial varieties currently grown in Brazil are asymptomatic carriers of the disease, correct diagnosis constitutes one of the main measures for successful control. The present study aimed to examine the efficiency of different diagnostic methods for $X$. albilineans. The obtained data demonstrated that the classic method for the pathogen isolation in culture media from the sap of the culm internodes was not reliable, whereas the amplification method by PCR detected the bacterium in plants with the three different symptoms of the disease.

Additional keywords: Diagnosis, latent symptoms, DNA, PCR, Saccharum.

A crescente conscientização dos graves problemas ambientais advindos da queima de energia fóssil faz com que todos os países do mundo procurem por fontes alternativas viáveis que possam substituir o petróleo. Nesse sentido, o Brasil se destaca por ter sucesso na substituição de uma fonte altamente poluente por uma renovável, que tem se mostrado economicamente viável graças à cana-de-açúcar. $\mathrm{O}$ etanol produzido da cana tem se mostrado uma alternativa confiável de substituição à gasolina nos motores automotivos, principalmente após o advento dos carros bicombustível. Some-se ainda a utilidade da cana-de-açúcar como fonte de energia, visto que após a retirada do suco (transformado posteriormente em açúcar ou etanol), o bagaço e a palha são usados na co-geração de energia fornecendo energia térmica, elétrica e mecânica, tanto para consumo da própria usina como para venda às companhias elétricas.

A demanda por etanol aumenta a cada ano devido à procura pelos carros flex, que cresce a uma proporção maior que a produção de canade-açúcar, fazendo com que a procura por esse tipo de carro seja maior que a produção de etanol hidratado. $\mathrm{O}$ açúcar também sofre uma forte valorização, pois tanto a safra brasileira, que responde por $44 \%$ do comércio mundial, como a indiana, outro grande fornecedor, sofreu redução da produção fazendo com que a perspectiva para a cana-deaçúcar do Brasil seja altamente favorável (1).

As estratégias que as usinas estão usando para atender à crescente demanda pelo produto se concentram na expansão da cultura para 
novas áreas e no aumento de produtividade em regiões tradicionais. A área com a cultura teve aumento significativo nos principais estados produtores na safra 2011/2012, onde S. Paulo se destacou com expansão de 203.834 ha da área existente, Minas Gerais com 152.427 ha, Goiás com 123.485 ha, Mato Grosso do Sul com 58.488 ha e Mato Grosso com 18.192 ha, totalizando 621.505 ha em todo o país (1). Esse constante incremento de novas áreas traz uma preocupação aos pesquisadores envolvidos com a cultura, pois muitas doenças importantes podem ser disseminadas através das mudas empregadas nessa expansão. Doenças como mosaico (Sugarcane mosaic virus), o raquitismo-da-soqueira (Leifsonia xyli subsp xyli), a escaldadura das folhas (Xanthomonas albilineans) e o carvão (Sporisorium scitamineum) tem nos toletes um eficiente meio de disseminação para novas áreas (8).

Dentre essas, a escaldadura das folhas é considerada uma das mais graves por afetar a qualidade do caldo da cana (9), causar morte de plantas em extensas áreas (4), estar disseminada em praticamente todas as regiões produtoras do Brasil e do mundo e ser de difícil identificação por apresentar sintoma latente (8).

A utilização de toletes provenientes de plantas doentes, porém assintomáticas faz com que a doença se dissemine facilmente para outras regiões. Uma vez plantada no campo, e sob condições de estresse climático, canas aparentemente sadias começam a apresentar sintoma agudo de escaldadura com queima das folhas, colapso súbito e morte de plantas (4). Relatos de ocorrência da doença e conseqüente dano à produtividade foram verificados nos Estados Unidos, México, Guatemala e Cuba (9).

Portanto, uma das principais medidas de controle da doença se concentra na sua correta diagnose, principalmente das canas assintomáticas, para que as mesmas possam ser descartadas antes dessas serem utilizadas como mudas. No Brasil, apesar da importância da cultura para a economia brasileira, pouca informação está disponível sobre os métodos que poderiam ser empregados para o exame diagnóstico da escaldadura-das-folhas.

Dentre os métodos de diagnose conhecidos estão o isolamento em meio de Wilbrink (8) ou meio semi-seletivo (3), sorológicos com antissoro mono ou policlonal (2) e os moleculares baseados na técnica de em PCR, com emprego de diversos conjuntos de "primers" $(7,10)$.

Devido à falta de consenso sobre o método mais sensível de detecção da bactéria, já que para alguns pesquisadores o isolamento em meio semi seletivo se mostrou muito mais sensível que os métodos sorológicos e PCR (10), enquanto que para outros, a detecção da bactéria por isolamento em meio de cultura e sorologia a partir dos sintomas latentes não é confiável pela baixa concentração ou distribuição desigual do patógeno dentro dos tecidos da planta $(2,3,6)$, o presente trabalho objetivou comparar o método de diagnose por isolamento do patógeno com o método baseado na amplificação de DNA total por PCR, utilizando-se de "primers" específicos.

Dez touceiras distintas do clone RB955434 com 12 meses de idade e que apresentavam perfilhos com os três tipos de sintomas de escaladadura-das-folhas foram empregadas nesse trabalho. De cada touceira foram separadas perfilhos com cada tipo de sintoma, extraindo-se, por centrifugação a 3000rpm por $15 \mathrm{~min}$ a seiva do internódio mais basal, mediano (quinto ou sexto entrenó) e apical (nono ou décimo entrenó).

A constatação da presença de $X$. albilineans foi feita por dois métodos. No método convencional, 100 ì 1 da seiva obtida dos diferentes internódios foram espalhados na superfície da placa de Petri com Wilbrink (8) ou XAS sem inibidores (3) em três repetições para cada um dos internódios, totalizando 90 amostras para cada um dos meios de cultura. A incubação foi feita a $26^{\circ} \mathrm{C}$, no escuro, por 6-7 dias, já que após esse período o crescimento das bactérias impossibilitava a individualização das mesmas. A confirmação da presença da bactéria em ambos os meios foi realizada pelo método molecular, após purificação das colônias suspeitas.

No método molecular, o DNA total foi extraído de 1,5 $\mathrm{g}$ de tecido dos diferentes internódios provenientes de perfilhos com os diferentes tipos de sintoma, de acordo com Murray \& Thompson (5). As condições de amplificação por PCR foram realizadas segundo Pan et al. (7) utilizando-se os "primers" PGBL1 e PGBL2 propostos pelos autores. Os produtos da amplificação foram visualizados por meio de eletroforese em gel de agarose $2 \%$ e tampão $1 \mathrm{X}$ de Tris-Borato-EDTA corados com brometo de etídio. Duas amostras foram empregadas como controle negativo: isolado de X. campestris pv. campestris, proveniente de couve e água milliQ autoclavada em substituição ao DNA molde. Como controles positivos também foram utilizados amostras de cultura pura de $X$. albilineans isolado ScXa01-01 e de seiva de uma planta com sintoma agudo de queima das folhas e brotação lateral causada pela doença.

A obtenção dos três tipos de sintomas distintos que caracterizam a escaldadura-das-folhas na cana-de-açúcar numa mesma touceira foi o diferencial que permitiu a condução deste trabalho. Esse tipo de amostragem não tinha sido empregada nos estudos realizados anteriormente $(2,10)$ e permitiu comparar a eficiência dos diferentes métodos diagnósticos de escaldadura-das-folhas, em função dos sintomas apresentados pela planta doente (Tabela 1).

Muitos fungos e colônias bacterianas de diferentes morfologias foram obtidos nos dois meios de cultura empregados (Figura 1). Das colônias bacterianas, todas aquelas semelhantes a $X$. albilineans, que se caracterizam por coloração amarela brilhante, convexas, bordos lisos, viscosas e não mucóides (8), foram posteriormente submetidas a diagnose molecular, o que permitiu avaliar com segurança a eficiência de cada meio de cultura em isolar a bactéria. $\mathrm{O}$ isolamento em meio de cultura XAS sem inibidores se mostrou mais eficiente que o de Wilbrink visto que crescimento do patógeno foi verificado em amostras de caldos advindos dos três tipos de sintomas, embora os valores da

Tabela 1. Porcentagem de detecção de Xanthomonas albilineans em função da altura dos internódios na planta de onde foi feita a coleta da seiva, tipo de sintoma e método de detecção.

\begin{tabular}{|c|c|c|c|c|c|c|c|c|c|}
\hline \multirow{2}{*}{ Internódios } & \multicolumn{3}{|c|}{ Wilbrink } & \multicolumn{3}{|c|}{ XAS } & \multicolumn{3}{|c|}{ PCR } \\
\hline & Latente & Crônico & Agudo & Latente & Crônico & Agudo & Latente & Crônico & Agudo \\
\hline Mediano & 0 & 10 & 0 & 0 & 40 & 10 & 100 & 100 & 100 \\
\hline Basal & 0 & 30 & 0 & 10 & 10 & 30 & 100 & 100 & 100 \\
\hline
\end{tabular}


porcentagem de detacção do patógeno tenham sido distintos em função da posição do internódio no colmo e do tipo de sintoma. No entanto, nenhuma das dez amostras advindas dos colmos da região mediana da planta com sintoma latente apresentou crescimento positivo do patógeno. O meio de cultura Wilbrink teve desempenho inferior ao de XAS, não apresentando crescimento da bactéria nas amostras com sintoma latente e mesmo em plantas sintomáticas, o nível de detecção não ultrapassou $30 \%$. Nos dois meios de cultura empregados, a recuperação da bactéria se deu de forma errática, não apresentando correlação ao tipo de sintoma e posição do internódio no colmo da planta. Em plantas com sintoma latente a porcentagem de crescimento da bactéria foi zero (meio Wilbrink) ou muito baixo (meio XAS sem inibidores) e mesmo nas sintomáticas a eficiência de detecção pode ser considerada baixa (Tabela 1). Nenhuma tentativa de incorporação de inibidores para aumentar a eficiência desses meios foi realizada, embora o meio XAS tenha tido um desempenho superior ao de Wilbrink na detecção de $X$. albilineans.

Esses dados do presente trabalho estão de acordo com os observados por Comstock et al. (2). Os autores verificaram que quando o método de detecção de $X$. albilineans for feito através do isolamento da bactéria em meio de cultura, a posição do internódio no colmo da

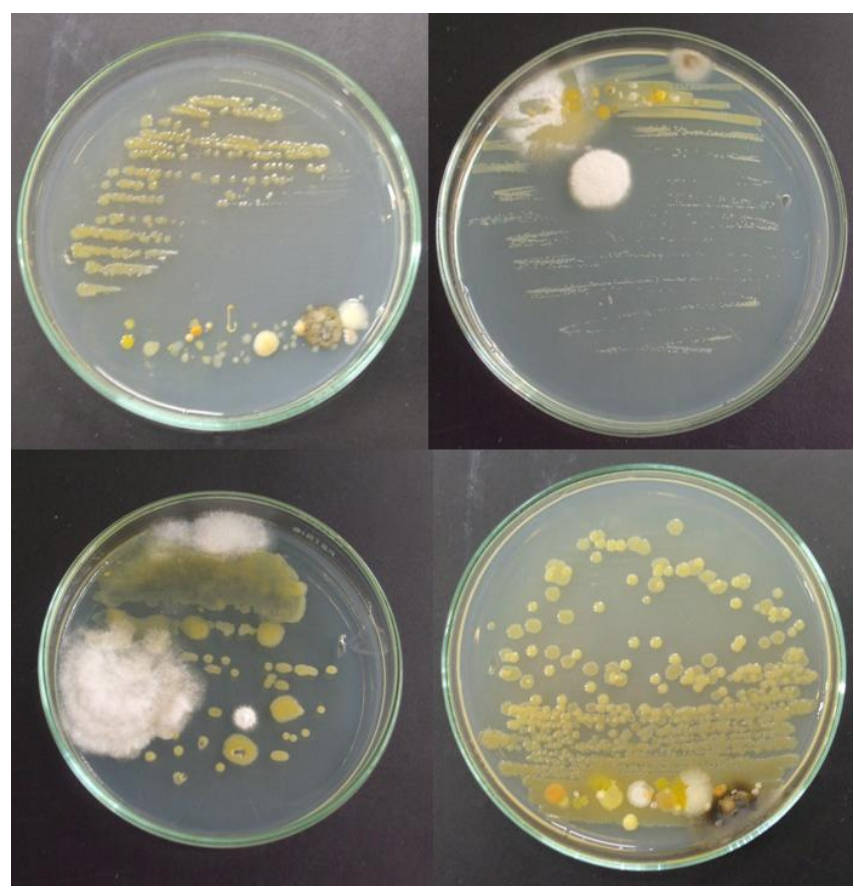

Figura 1. Colônias de bactérias e fungos aos sete dias em meio Wilbrink e XAS sem inibidores, oriundas do isolamento a partir de seiva de cana-deaçúcar com sintoma crônico (direita) e agudo (esquerda) de escaldaduradas-folhas. planta para a extração do caldo teve influência na recuperação da bactéria, apresentando portanto, baixa confiabilidade. Entretanto, segundo Davis et al. (3), em estudos realizados para avaliar métodos de isolamento e imunológicos na detecção de X. albilineans, o isolamento em meio semi-seletivo foi o método mais eficiente de detecção. Resultados semelhantes foram também descritos por Wang et al. (10) (Tabela 1).

De acordo com a literatura, os métodos imunológicos de detecção da bactéria, como ELISA ("Enzime-linked Immunosorbent Assay") e TBIA ("Tissue Blot Enzime Immunoassay") (2,3,10), também apresentam falhas, sendo que nenhum deles foi capaz de detectar a doença em $100 \%$ dos casos, mesmo em plantas sintomáticas. As razões para tal insucesso variaram desde alto nível de contaminação por outras bactérias habitantes dos vasos condutores da cana-deaçúcar (3), a distribuição desuniforme da bactéria nas diferentes partes da planta (9) e baixo título da bactéria na seiva extraída de colmos de cana com sintoma latente quando comparado com os caldos de plantas sintomáticas (3). No presente trabalho, a superioridade do método molecular ficou evidente pela detecção em $100 \%$ dos casos, independentemente do tipo de sintoma apresentado pela planta e o local de retirada da seiva no internódio da planta (Figura 2). Os produtos de PCR obtidos a partir de caldos advindos de colmos da parte basal, mediana e superior de plantas assintomáticas, resultaram em um fragmento específico esperado de 288 pares de bases (PB).

A crescente mecanização na cultura de cana-de-açúcar faz com que o método diagnóstico de doenças ganhe destaque e seja um dos principais requisitos para o sucesso das estratégias de controle de doenças. Isso porque o material propagativo empregado na implantação da cultura pode servir de fonte de inóculo primário de doenças que são transmitidas através de mudas contaminadas (8), especialmente a longas distâncias, em áreas novas de expansão da cultura de cana-deaçúcar, o que está ocorrendo em todas as regiões produtoras do Brasil (1). Uma vez a doença instalada na lavoura, a transmissão para outras plantas dentro do mesmo campo vai se dar especialmente através de facões e colheitadeiras (9). Nesse contexto, o presente trabalho mostrou que o método diagnóstico molecular foi eficiente em $100 \%$ das amostras de plantas doentes assintomáticas, se constituindo em ferramenta importante na detecção da escaldadura-das-folhas.

Embora a técnica BIO-PCR tenha apresentado melhores resultados que o PCR normal na detecção de escaldadura-das-folhas (10), resultados do presente estudo demonstraram que o PCR convencional pode ser o empregado pois conseguiu detectar a doença de todas as plantas assintomáticas. A técnica BIO-PCR necessita que o patógeno cresça em meio artificial por quatro dias enquanto no presente trabalho a extração do DNA do tecido foi feita em um dia, proporcionado uma rapidez na diagnose, sem gasto adicional de tempo, vidraria e reagentes.

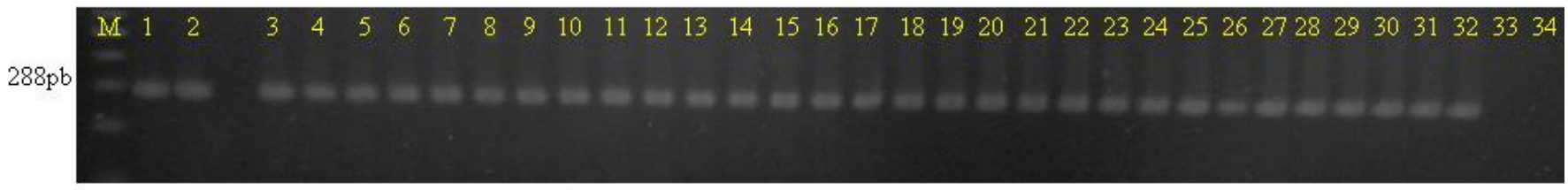

Figura 2. Amplificação do DNA genômico de plantas de cana-de-açúcar com sintoma latente de escaldadura-das-folhas utilizando-se o par de primers PGBL1/PGBL2. (M): marcador de peso molecular (1); cultura pura do isolado ScXa01-01 de Xanthomonas albilineans (2); seiva do internódio basal de colmos de cana-de-açúcar com sintoma latente de escaladadura-das-folhas (3-12); seiva do internódio mediano de colmos de cana-de-açúcar com sintoma latente de escaladadura-das-folhas (13-22); seiva do internódio apical de colmos de cana-de-açúcar com sintoma latente de escaladadura-das-folhas; controle negativo sem DNA (33); cultura pura de X. campestris pv. campestris (34). 


\section{REFERÊNCIAS BIBLIOGRÁFICAS}

1. Companhia Nacional de Abastecimento (CONAB). Acompanhamento da safra brasileira: cana-de-açúcar: safra 2011/2012: segundo levantamento, Agosto/2011. Companhia Nacional de Abastecimento - Brasília: Conab 2011. Disponível em: http:// www.conab.gov.br/OlalaCMS/uploads/arquivos/ $11_{-} 08_{-} 300_{-} 13_{-} 41_{-} 19_{-}$boletim_cana_portugues _agosto_2011_2o_lev..pdf. Acesso em: 08 Nov. 2011.

2. Comstock, J.C.; Irey, M.S. Detection of the sugarcane leaf scald pathogen, Xanthomonas albilineans, using tissue blot immunoassay, ELISA, and isolation techniques. Plant Disease, Saint Paul, v.76, n.10, p.1033-1035, 1992.

3. Davis, M.J.; Rott, P.; Baudin, P.; Dean, J.L. Evaluation of selective media and immunoassays for detection of Xanthomonas albilineans, causal agent of sugarcane leaf scald disease. Plant Disease, Saint Paul, v.78, n.1, p.78-82, 1994.

4. Hoy, J.W.; Grisham, M.P. Sugarcane leaf scald distribution, symptomatology, and effect on yield in Louisiana. Plant Disease, Saint Paul, v.78, n.11, p.1083-1087, 1994.
5. Murray, M.G.; Thompson, W.F. Rapid isolation of high molecular weight plant DNA. Nucleic Acids Research, Oxford, v.8, n.19, p.4321-4325, 1980

6. Pan, Y.B.; Grisham, M.P.; Burner, D.M. A polymerase chain reaction protocol for the detection of Xanthomonas albilineans, the causal agent of sugarcane leaf scald disease. Plant Disease, Saint Paul, v.81, n.2, p.189-194, 1997.

7. Pan, Y.B.; Grisham, M.P.; Wei, Q.. PCR diagnosis of sugarcane leaf scald and ratoon stunting disease. Proceeding International Society Sugar Cane Technologist, v.24, p.607-608, 2001.

8. Ricaud, C.; Egan, B.T.; Gillapie Jr, A.G.; Hughes, C.G. (eds.) Diseases of sugarcane: major diseases. Amsterdam: Elsevier, 1989.

9. Saumtally, A.S.; Dookun-Saumtally, A. Leaf scald of sugarcane: a disease of worldwide importance. In: Rao, G.P.; Saumtally, A.S.; Rott, P. Sugarcane pathology: bacterial and nematode diseases. New Hampshire: Science Publishers, 2004. v.3, p.65-76.

10. Wang, Z.K.; Comstock, J.C.; Hatziloukas, E.; Schaad, N.W. Comparison of PCR, BIO-PCR, DIA, ELISA and isolation on semiselective medium for detection of Xanthomonas albilineans, the causal agent of leaf scald of sugarcane. Plant Pathology, Oxford, v. 48, n.2, p.245-252, 1999. 